\title{
PHYSICAL AND MECHANICAL PROPERTIES OF CANTALOUPE APPLIED TO DESIGN SEED- EXTRACTION MACHINE
}

\author{
I. Yehia ${ }^{(1)}$, E. M. Arif ${ }^{(2)}$, A. M. El Lithy ${ }^{(3)}$ and M. M. Atallah $^{(4)}$
}

ABSTRACT

The aim of this research is to study some physical and mechanical properties of cantaloupe, as promising fruits, to help the design of handling machines. The physical and mechanical properties are incorporated in the development of the seed-extraction machine as a case study.

The main results in this study can be summarized as follows:

Physical properties of cantaloupe fruits: diameter $=82.12-113.51 \mathrm{~mm}$, height $=82.07-119.95 \mathrm{~mm}$, mass $=329.2-940.6 \mathrm{~g}$, volume $=380-860$ $\mathrm{cm}^{3}$, projected area $=85.85-160.95 \mathrm{~cm}^{2}$, real density $=0.69-1.08$ $\mathrm{g} / \mathrm{cm}^{3}$, bulk density $=0.51 \mathrm{~g} / \mathrm{cm}^{3}$, sphericity $=0.88-1.07$.

Mechanical properties: the average of cantaloupe-fruit firmness was 62.5 $\mathrm{N} / \mathrm{cm}^{2}$, the maximum $=80.4 \mathrm{~N} / \mathrm{cm}^{2}$ and the minimum $=28.6 \mathrm{~N} / \mathrm{cm}^{2}$.

The physical and mechanical properties are incorporated in the design of the cantaloupe-fruit convey tube, holding mechanism and separated mechanism (vibrated chain-belt) of the designed seed-extraction machine is given also in the paper as a case study.

\section{INTRODUCTION}

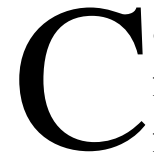

antaloupe (Cucumis melo) is a subtropical fruits and belongs to family Cucurbitaceae. Cantaloupe is considered as one of the best fruits due to its high mutritive value. Besides a rich source of vitamin $\mathrm{A}$ and $\mathrm{C}$, it contains a fair amount of nutrients (calcium, magnesium, phosphorus, potassium and iron) and vitamins B1, B3 and B5. Cantaloupe contains $55-59 \%$ edible portion, $87-92 \%$ moisture, $0.1-0.2 \%$ oil, $0.6-1.0 \%$ protein and $6.3-10.3 \%$ total soluble solids (Arabsalmani, 1996). Cantaloupe is the major horticultural crop in Egypt.

(1), (2) and (4) Chief Res., Senior Res. and Res., Ag. Eng. Res. Inst. Respectively, (3) Associ. Prof, Ag. Eng., Ag. Col., Azhar U., Assuit. 
The cultivated area of cantaloupe is 74.147 thousand feddans (31.14 thousand hectare) in 2009 and the annual production is about 755.6 thousand ton in 2009. (Ministry of Agriculture, 2009).

Many authors \{Akubuo and Odigboh (1999), Abou-Elmagd, et al. (2002), Awady et al. (2004), El Sayed et al. (2009) and Yehia et al. (2009)\} mentioned that the knowledge of the physical and mechanical characteristics of agricultural products is important in the design, of agricultural machines and equipment. They studied the physical properties and characteristics of some agricultural crops and fruits, which can be used in the design and development of equipment. Abou-EImagd, et al. (2002) designed and tested a crushing machine for watermelon seeds-extraction. The machine consists of hopper, crushing drum with knives, screw conveyer and water source.

Ghanbarian et al. (2008) found that the average masses of cantaloupe fruits were 697 to $1272 \mathrm{~g}$, the fruit volumes were 1084 and $1409 \mathrm{~cm}^{3}$ and geometric mean diameters were 11.7 and $13.12 \mathrm{~cm}$ for Samsouri and shahabadi varieties respectively.

Rashidi and Seyfi (2007) found that the mass of cantaloupe fruit (Samsouri variety) ranges from about 510 to $3380 \mathrm{~g}$, the fruit volume from 538 to $3654 \mathrm{~cm}^{3}$ and the length from 95 to $185 \mathrm{~cm}$, Major diameter from 106 to $205 \mathrm{~cm}$, Minor diameter from 101 to $190 \mathrm{~cm}$ and density from 0.78 to $1.07 \mathrm{~g} / \mathrm{cm}^{3}$.

Hassan (1994) reported that the methods of extracting vegetable seeds from soft fruits include the following steps: 1) Cutting and smashing the fruits mechanically as in tomatoes and watermelons or cutting them into two-halves manually using a knife as in sweet melon. 2) Extracting seeds from surrounding gelatin and smashed fruit parts by leaving the mixture from 2 to 4 days to ferment as in tomatoes or proceeding extraction mechanically as in different cucurbitaceae, pepper, eggplant and tomato. 3) Washing seed using running water. 4) Drying seeds naturally in drying climate or by exposing them to current of warm air in humid climate.

Vergano et al. (1992) studied the design aspects and performance of an axial-flow vegetable seed extracting machine. They compared the manual with the mechanical seed extraction for different vegetable fruits. They found that the manual seed extraction output was $0.47,1.20,1.26,1.56$, 
$1.83,2.20$ and $3.14 \mathrm{~kg} / \mathrm{man}-\mathrm{h}$ for cucumber, watermelon, tomato, summer squash, brinjal, squash melon and chillies, respectively. Meanwhile, the productivity of the seed extracting machine varied from 310 to $1930 \mathrm{~kg} / \mathrm{h}$ for all investigated vegetable fruits. They added that germination count for mechanically extracted seeds was higher than for the manually extracted seeds.

The objective of the present research is to study some physical and mechanical properties of cantaloupe fruits, as a data base, for promising fruits, to help the design of handling machines. The physical and mechanical properties are incorporated in the development of the seedextraction machine as a case study.

\section{MATERIALS AND METHODS}

\section{a. Fruits.}

Cantaloupe crop Galia variety was considered in this study. All measurements were done using a random sample of 100 fruits. The samples were taken randomly from cantaloupe trees (special farm in El Sharkia Governorate (محافظة الثرقية) at acceptable harvesting date) and from "El Oboor" (سوق العبور) Market; and the measurements were taken in the same day.

\section{b. Instrumentation:}

b1. Digital caliper with vernier: with accuracy of $0.01 \mathrm{~mm}$, to measure different dimensions of cantaloupe fruits.

b2. Digital balance: with accuracy of $0.2 \mathrm{~g}$, to measure mass of cantaloupe fruits.

b3. Graduated cylinder: of $2000 \mathrm{~mL}$ with accuracy of $25 \mathrm{~mL}$ to determine the real density and volume of fruit by immersion in water.

b4. Friction and rolling-angle measuring device: An inclined plane was used to measure friction and rolling angles.

b5. Friction and repose angle measurement: the fruits are placed as a group bounded together on a horizontal surface then the angle of inclination is gradually increased until the fruits begin sliding without 
rolling. For each fruits group of an average sample of (10), the friction and repose angles were determined.

b6. Rolling angle measurement: the fruits are placed on a horizontal surface one by one then the angle of inclination is gradually increased until the fruits begin to roll. For each fruit of an average sample (50), two angles of rolling are determined: for the maximum stable (with their base down) and minimum stable positions.

b.7 Penetrometer: Penetrometer, made in Italy, with accuracy of $0.1 \mathrm{~N}$ was used to measure penetration force of cantaloupe fruits. The firmness of fruit was obtained by dividing the penetration force by the area $(0.28$ $\mathrm{cm}^{2}$ ) of cylindrical probe with circular edge, which had $0.6 \mathrm{~cm}$ diameter.

\section{c. Equations and calculations:}

The following equations were used to calculate sphericity, projected area and real density according to Mohsenin, 1986 and Wilhelm et al., 2005 (fig. 1).

Sphericity ratio $=\mathrm{D} / \mathrm{H}$

Where:

$\mathrm{H}=$ Fruit height, $\mathrm{mm}$,

$\mathrm{D}=$ Diameter of fruit, $\mathrm{mm}$,

Projected area $=4 / \pi(D * H)$

Real density $=$ Mass $/$ Volume

\section{d. The developed seed-extraction machine:}

Fig. 2 shows a schematic diagram of a design-idea of cantaloupe seedextraction machine. Parameters shown on the figure are essentially those to be determined for cantaloupe through this work, for modifying the seed-extraction machine to operate efficiently on this fruit.

$\mathrm{D}=\mathrm{D}_{1}=\mathrm{D}_{2}$

for studied varieties

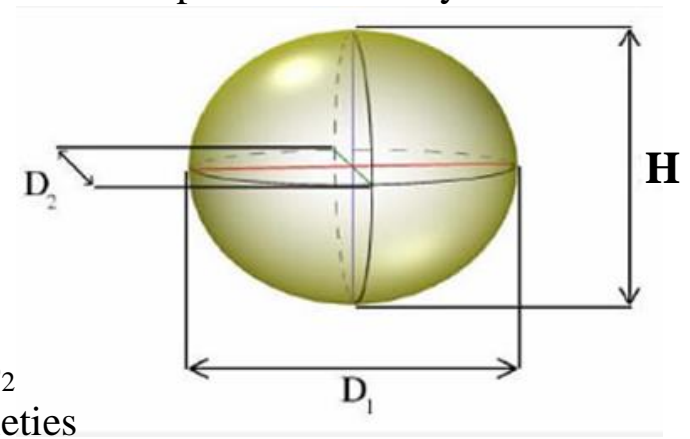

Fig. 1: View of cantaloupe fruit. 


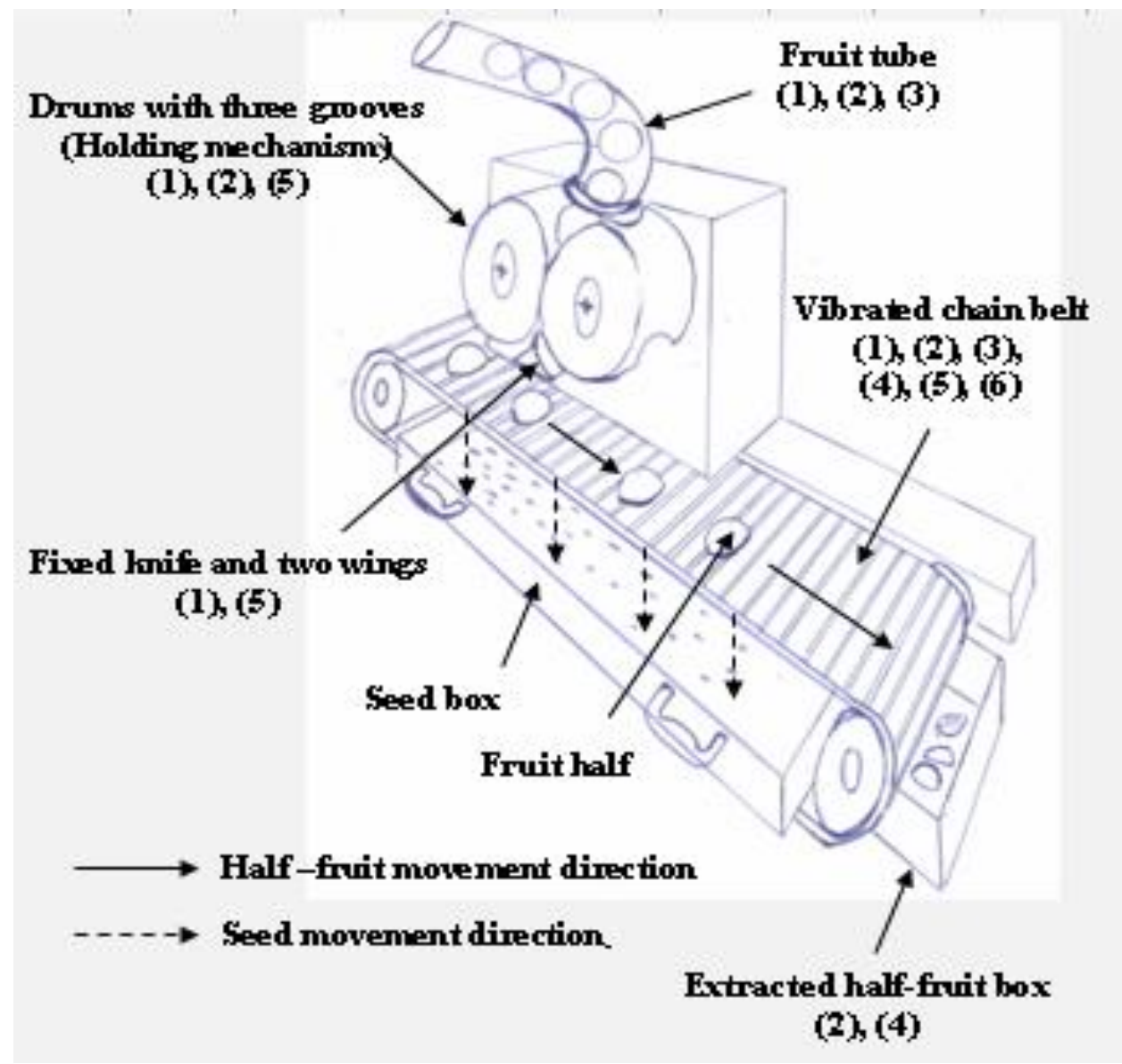

Fig. 2: Diagram demonstrating idea of extracting machine, with the numbers in brackets indicating parameters necessary for design of different parts.

\section{Associated parameters:}

(1) Fruit dimensions, (2) Bulk density, (3) Friction and rolling angles,

(4) Fruit mass, (5) Fruit firmness, and (6) Seed size.

\section{RESULTS AND DISCUSSION}

\section{a. Physical properties of cantaloupe fruits.}

Table 1 shows dimensions, sphericity, mass, volume, real density, projected area, mass, juice volume and seed No./fruit of cantaloupe. These data were measured on 100 fruit sample, according to the standards set in (Mohsenin, 1986 and Wilhelm et al., 2005). 
Table 1: Physical properties of cantaloupe fruits.

\begin{tabular}{|l|c|c|c|c|c|}
\hline Physical properties & Max. & Min. & Average & S. D. $^{(1)}$ & C. V. $^{(2)}$ \\
\hline Height, $\mathrm{mm}$ & 119.95 & 82.07 & 96.29 & 8.88 & 9.22 \\
\hline Diameter, mm & 113.51 & 82.12 & 95.65 & 7.89 & 8.25 \\
\hline Sphericity & 1.07 & 0.88 & 0.99 & 4.00 & 4.24 \\
\hline Mass, g & 940.60 & 329.20 & 555.93 & 159.81 & 28.75 \\
\hline Volume, $\mathrm{cm}^{3}$ & 860 & 380 & 620 & 142.62 & 23.95 \\
\hline Bulk density, g/cm ${ }^{3}$ & \multicolumn{5}{|l|}{0.501} \\
\hline Real density, g/cm ${ }^{3}$ & 1.08 & 0.69 & 0.90 & 9.00 & 10.49 \\
\hline Projected area, cm ${ }^{2}$ & 160.95 & 85.85 & 118.08 & 20.04 & 16.97 \\
\hline No. of seeds/fruits & 585 & 413 & 498 & 18.58 & 17.06 \\
\hline
\end{tabular}

(1) S. D. is standard deviation.

(2) C. V. is coefficient of variation.

\section{a1. Dimensions of fruit:}

Fig. 3 indicates that the fruit diameter, height and geometric diameter ranges of sample were 82.12 - $113.51 \mathrm{~mm}$ (average $95.65 \mathrm{~mm}$ ), 82.07 $119.95 \mathrm{~mm}$ (average $96.29 \mathrm{~mm}$ ) and $82.10-112.64 \mathrm{~mm}$ (average 95.97 $\mathrm{mm})$ respectively. The most frequent percent $(88.2 \%)$ of cantaloupe fruits in the sample have $85-105 \mathrm{~mm}$ diameter, $(85.3 \%)$ of cantaloupe fruits in the sample have $85-105 \mathrm{~mm}$ height and $(85.3 \%)$ of cantaloupe fruits in the sample have $85-105 \mathrm{~mm}$ geometric diameter.

\section{a2. Shape and size of fruit:}

If sphericity is less than 0.9 , the fruit belongs to oblate group; if sphericity is greater than 1.1, it belongs to oblong group. The remaining fruits with intermediate index values are considered to be round (Buyanov and Voronyuk, 1985).

Fig. 4 indicates that the fruit spericity ranged in sample between 0.7 and 1.3. The most frequent percent $(97.1 \%)$ of cantaloupe fruits in the sample was round (sphericity $0.9-1.1)$ and $(2.9 \%)$ of cantaloupe fruits in the sample were oblate (sphericity 0.88 ).

\section{a3. Mass and volume of fruit:}

Fig. 5 indicates that the fruit mass and volume ranges of sample were $329.2-940 \mathrm{~g}$ (average $555.93 \mathrm{~g}$ ) and $380-860 \mathrm{~cm}^{3}$ (average $595.41 \mathrm{~cm}^{3}$ ) respectively. The most frequent percent $(79.4 \%)$ of cantaloupe fruits in the sample had $400-700 \mathrm{~g}$ mass and $(76.5 \%)$ had $500-700 \mathrm{~cm}^{3}$ volume. 


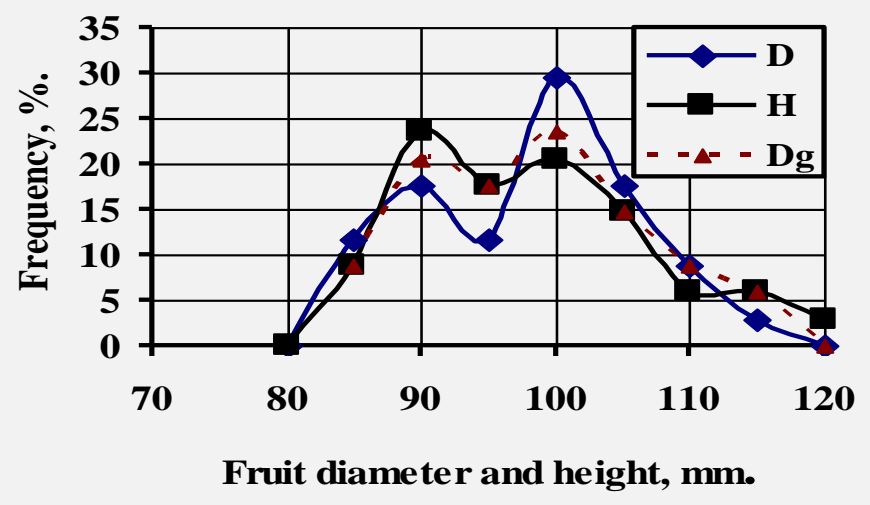

Fig. 3: Frequency curves distribution of fruit dimensions (diameter "D" , geometric diameter " $\mathrm{D}_{\mathrm{g}}$ "and height " $\mathrm{H}$ ") of cantaloupe fruits.

\section{a4. Real density of fruit:}

Fig. 6 indicates that the fruit real density of sample ranged between 0.69 and $1.08 \mathrm{~g} / \mathrm{cm}^{3}$ (average $0.90 \mathrm{~g} / \mathrm{cm}^{3}$ ). The most frequent percent $(70.6 \%$ ) of cantaloupe fruits in the sample had $0.9-1.0 \mathrm{~g} / \mathrm{cm}^{3}$ real density.

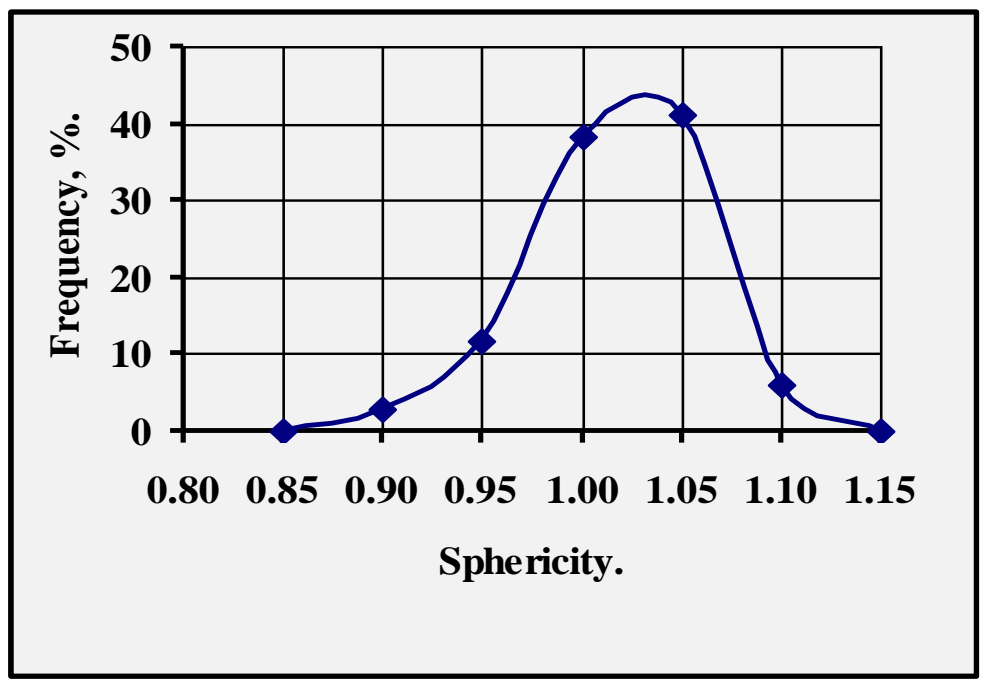

Fig. 4: Frequency distribution of fruit sphericity of cantaloupe fruits. 


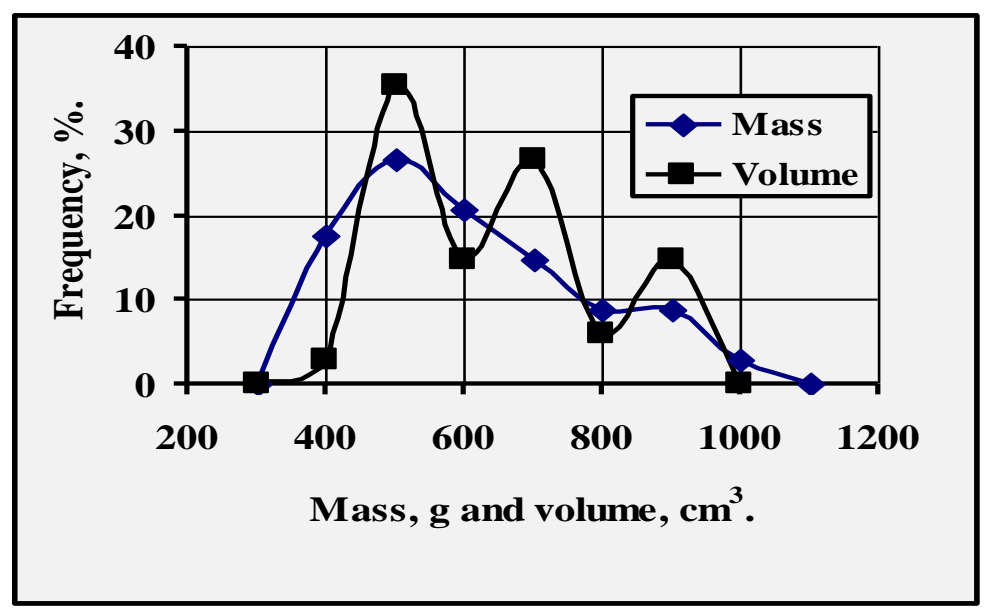

Fig. 5: Frequency curves distribution of fruit mass and volume of cantaloupe fruits.

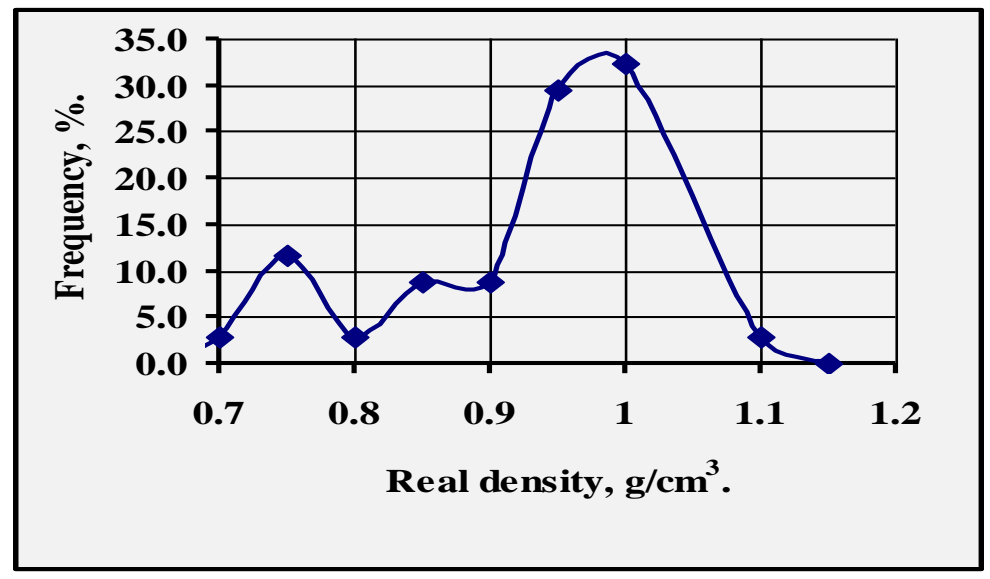

Fig. 6: Frequency curve distribution of fruit real-density of cantaloupe fruits.

\section{a5. Projected area of fruit:}

Fig. 7 indicates that the fruit projected area of sample ranges between 85.85 and $160.95 \mathrm{~cm}^{2}$ (average $118.08 \mathrm{~cm}^{2}$ ). The most frequent percent $(73.55 \%)$ of cantaloupe fruits in the sample have $100-130 \mathrm{~cm}^{2}$ projected area. 


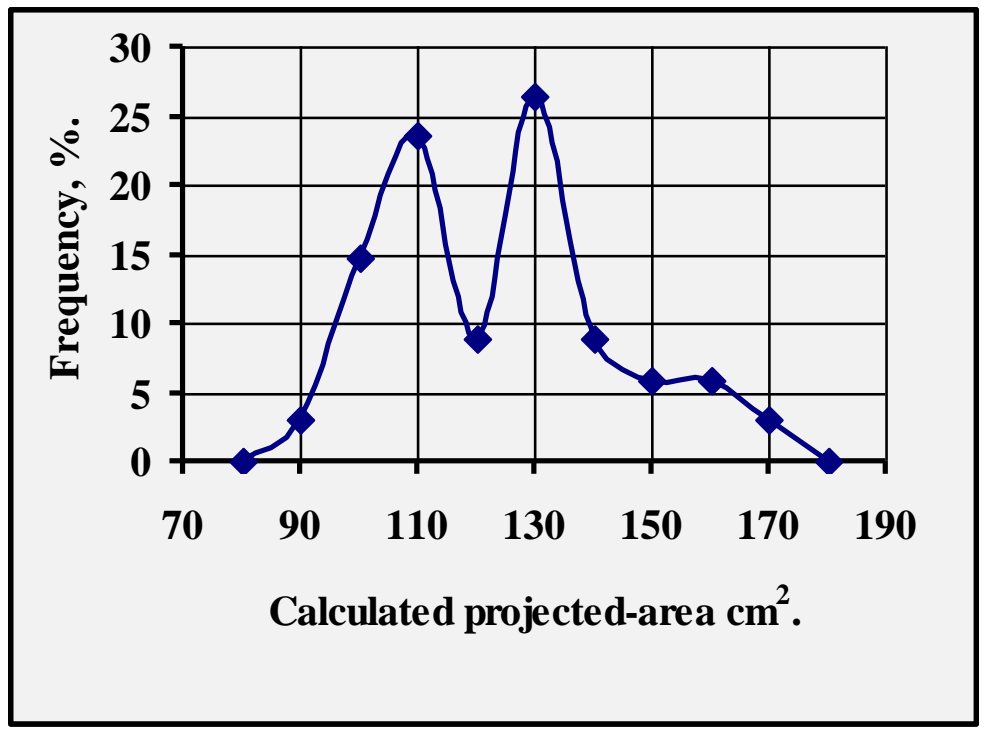

Fig. 7: Frequency curve distribution of fruit projected-area of cantaloupe fruits.

\section{b. Mechanical properties of cantaloupe fruits.}

\section{b1. Friction, rolling and repose angles of cantaloupe fruits:}

Table 2 shows friction and rolling angles of cantaloupe fruits. The maximum friction angle (28 - 34 degree) and rolling angle ranges (23 - 25 degree) were obtained with wood surface. Whereas, the minimum ranges of friction and rolling angles (9 - 12 and 11.8 - 14 respectively) were obtained with aluminium surface.

Table 2: Friction and rolling angles for cantaloupe fruits with different surface types.

\begin{tabular}{|c|c|c|c|c|c|c|c|c|c|}
\hline \multirow{2}{*}{$\begin{array}{c}\text { Surface } \\
\text { type }\end{array}$} & \multicolumn{3}{|c|}{$\begin{array}{c}\text { Friction angle, } \\
\text { degree }\end{array}$} & \multicolumn{6}{|c|}{ Rolling angle, degree } \\
\cline { 2 - 10 } & Max. & Min. & Av. & Max. & Min. & Av. & Max. & Min. & Av. \\
\hline Wood & 34 & 28 & 30 & 25 & 23 & 26 & 21 & 18 & 20 \\
\hline Metal & 12 & 10 & 10.3 & 25 & 15 & 20.3 & 15 & 10 & 12 \\
\hline Galv. I. & 12 & 10 & 10.7 & 25 & 15 & 20.5 & 15 & 10 & 12.2 \\
\hline Alum. & 12 & 9 & 10.4 & 23 & 15 & 20.1 & 14 & 10 & 11.8 \\
\hline SS & 12 & 10 & 10.5 & 25 & 15 & 20.2 & 15 & 10 & 11.9 \\
\hline
\end{tabular}

Misr J. Ag. Eng., April 2010 
Wood: wood sheet No. 2; Galv. I.: Galvanized iron; Alum.: Aluminium; and SS.: Stainless steal.

The average repose-angle was about 30.1 degree.

\section{b2. Firmness of cantaloupe fruits:}

The average of cantaloupe-fruit firmness was $62.5 \mathrm{~N} / \mathrm{cm}^{2}$, the maximum $=80.4 \mathrm{~N} / \mathrm{cm}^{2}$ and the minimum $=28.6 \mathrm{~N} / \mathrm{cm}^{2}$.

c. Application of the theory to the design of the cantaloupe seedextraction machine:

Parameters required for development of the design of seed-extraction machine have been explained in the part $2 d$ in the section on "Materials and Methods". Fig. 4 shows the parameters. Some results of this investigation point out to the following:

The physical and mechanical properties are incorporated in the design of the cantaloupe-fruit tube, holding mechanism and separated mechanism (vibrated chain-belt) of the designed seed-extraction machine as follows:

\section{Design of fruit tube (Fig. 3):}

Fruit-tube diameter $=$ Maximum diameter of cantaloupe fruits $=105 \mathrm{~mm}$.

Fruit-tube tilt angle $=$ more than maximum friction angle between cantaloupe fruits and stainless steal surface $=$ more than $25^{\circ}$.

\section{Design of holding mechanism :}

Groove diameter $=$ Maximum diameter of cantaloupe fruits $=115 \mathrm{~mm}$.

Groove depth $=$ Maximum diameter of cantaloupe fruits $/ 2=57.5 \mathrm{~mm}$.

No. of grooves $=3$ which give a suitable extracted fruit productivity.

Two-drum speeds $=$ about $30 \mathrm{rpm}$ which gives productivity of 90 fruit/min.

\section{Design of seprated mechanism:}

Vibrated-chain belt width $=$ more than maximum diameter of cantaloupe fruits $=200 \mathrm{~mm}$.

Distance between rods of chain belt $=$ more than seed size $=$ about $10 \mathrm{~mm}$.

\section{CONCLUSION}

The main results in this study can be summarized as follows:

Physical properties of cantaloupe fruits: diameter $=82.12-113.51 \mathrm{~mm}$, height $=82.07119 .95 \mathrm{~mm}$, mass $=329.2-940.6 \mathrm{~g}$, volume $=380-860$ $\mathrm{cm}^{3}$, projected area $=85.85-160.95 \mathrm{~cm}^{2}$, real density $=0.69-1.08$ $\mathrm{g} / \mathrm{cm}^{3}$, bulk density $=0.51 \mathrm{~g} / \mathrm{cm}^{3}$, sphericity $=0.88-1.07$. 
Mechanical properties: the average of cantaloupe-fruit firmness was 62.5 $\mathrm{N} / \mathrm{cm}^{2}$, the maximum $=80.4 \mathrm{~N} / \mathrm{cm}^{2}$ and the minimum $=28.6 \mathrm{~N} / \mathrm{cm}^{2}$.

The physical and mechanical properties are incorporated in the design of the cantaloupe-fruit tube, holding mechanism and separated mechanism (vibrated chain-belt) of the designed seed-extraction machine as follows:

Design of fruit tube: Fruit-tube diameter $=$ Maximum diameter of cantaloupe fruits $=105 \mathrm{~mm}$. Fruit-tube tilt angle $=$ more than maximum friction angle between cantaloupe fruits and stainless steal surface = more than $25^{\circ}$.

Design of holding mechanism: Groove diameter = Maximum diameter of cantaloupe fruits $=115 \mathrm{~mm}$. Groove depth $=$ Maximum diameter of cantaloupe fruits $/ 2=57.5 \mathrm{~mm}$. No. of grooves $=3$ which give a suitable extracted fruit productivity.

\section{REFERENCES}

Abou-Elmagd, A.E.; Hamam, A. S.; EL-Saadany, M. A. and ElKawaga, S. A., 2002, Design of a cone-end detacher for orange picking, Misr. J. Ag. Eng. 19(2): 491-507.

Abou-Elmagd, A.E.; Abd El-Mageed, H. N., Baiomey, M. A., and Sayed-Ahmed, I. F., 2006, Proper design and evaluation of an equipment for extracting watermelon seeds, J. Agric Sci. Mansoura Univ., 31(7): 53-68.

Akubuo, C.O. and Odigboh, E. U., 1999, Egusi fruit coring machine. J. Agric. Engng Res. 74: 121-126.

Arabsalmani, K., 1996, Evaluation of flowering, fruiting and effect of seed extraction time on seed quality characters of cantaloupe (cucumis melo), M. Sc., Th., Univ. of Tabriz, Iran: $65-80$.

Awady, M. N.; Yehia, I. Hassan, M. A. and El Lithy, A. M., 2004, Some physical and mechanical properties of Minneola fruits, Misr J. Ag. Eng., 21(2): 669-684.

Buyanov, A. I. And Voronyuk, B. A., 1985, Physical and mechanical properties of plants, Fertilizers and Soils, Amerind Pub. Co., PVT, LTD, New Delhi, Bombay, Calcutta, New York: 15 - 97. 
El Sayed, G. H., Harb, S., Yehia, I., and Arif, E. M., 2009, Development of an automatic juicer for minneola fruits, Misr J. Ag. Eng., 34(4): 4155-4167.

Hassan, A. A., 1994, Physiology, production and certification of vegetables seeds, $1^{\text {St }}$ Ed., El Dar El Arabia Pub., Cairo, Egypt (in Arabic): 130-137.

Ministry of Agriculture, 2009, Agricultural statistics, Economical Issues Sector, Cairo, Egypt: 84-107.

Mohsenin, N. N., 1986, Physical properties of plant and animal materials, Gordon and Breach Sc. Pub., N. Y.

Rashidi, M. and Seyfi, K., 2007, Classification of fruit shape in cantaloupe using the analysis of geometrical attributes, World J. of Ag. Sciences, Iran, 3(6): 735-740.

Vergano, P.J.; R.F. Testion; A.C. Choudhari and W.C. Newall. (1992). Peach vibration bruising: The effect of paper and plastic films between peaches. J. of Food Quality 15(3):183-197.

Wilhelm, L. R., Suter, D. A. And Brusewitz, G. H., 2005, Physical properties of food materials, Food and Processing Eng. Tech., ASAE, St. Joseph, Michigen, USA: $75-85$.

Yehia, I., Kabeel, M. H, and Abdel Galeel, M. M., 2009, Physical and mechanical properties of Ponkan mandarin applied to grading machine, Misr J. Ag. Eng. 26(2): 1036-1053.

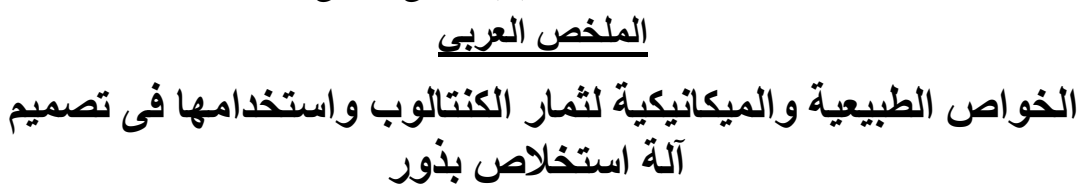

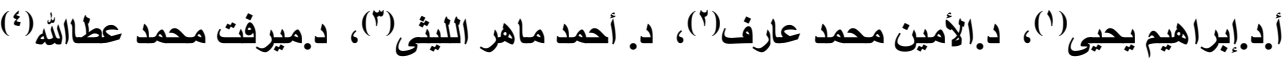
تهدف هذه الدراسة إلى تعيين الخو اص الطبيعية و الميكانيكية لثمار الكنتالوب، للاستفادة منها فى التى

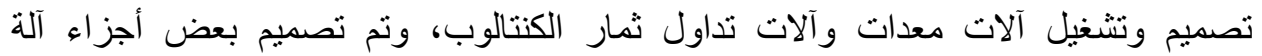
استخلاص بذور الكنتالوب كمثال. وتم الحصول على النتائج التالية:

$$
\begin{aligned}
& \text { ( ()، (Y)، ( ( ) رئيس بحوث، باحث أول و باحث على الترتيب، معهد بحوث الهندسة الزر اعية، }
\end{aligned}
$$

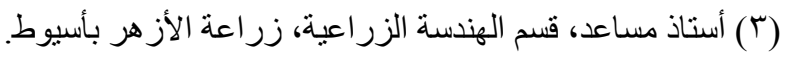




\section{(1) الخواص الطبيعية:}

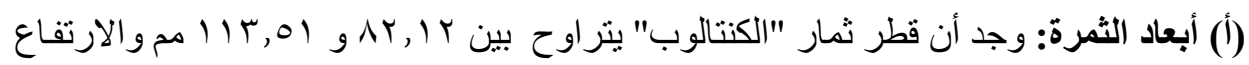

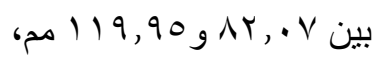

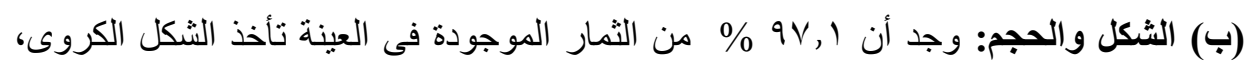

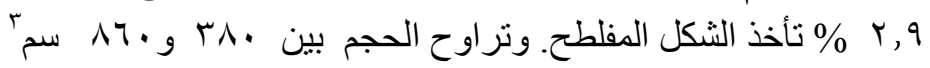

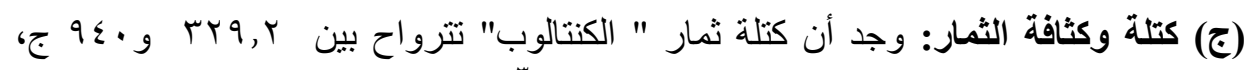

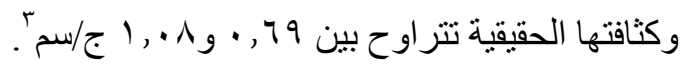

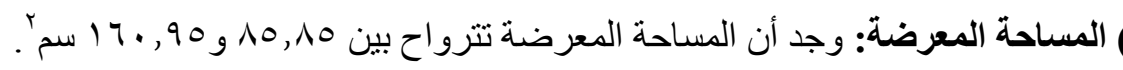

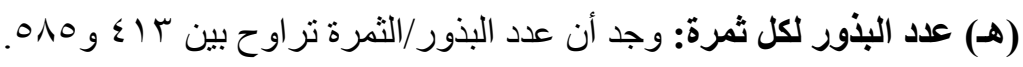

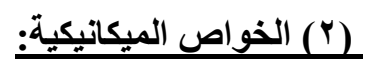

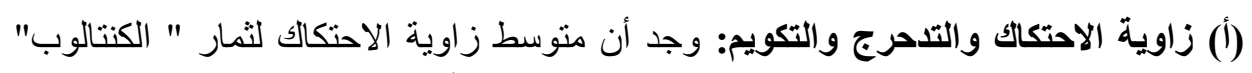

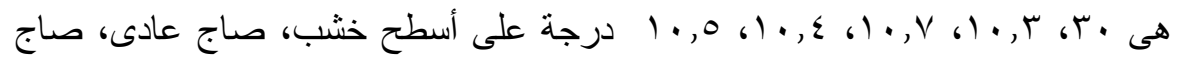

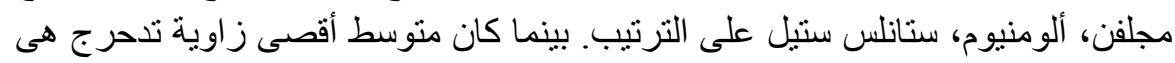

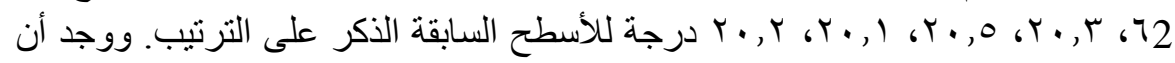

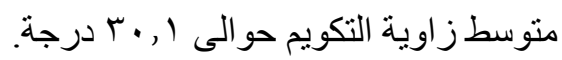

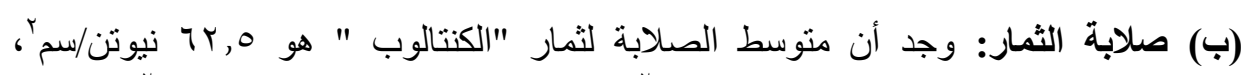

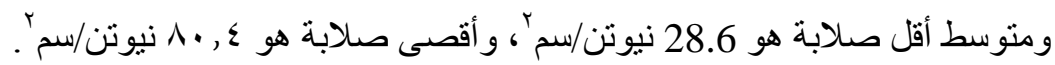
وفى داخل البحث فكرة لتصميم آلة لأستخلاص بذور الكنتالوب باستخدام الخو اص هـ الطبيعية و الميكانيكية للثمار . 